Makale türü / Article type: Araştırma / Research

\title{
Feminist Teori Temelinde Toplumsal Cinsiyet Eşitliğinin Türkiye Bağlamında Değerlendirilmesi ${ }^{1}$
}

****

\section{Evaluation of Social Gender Equality on the Basis of Feminist Theory within the Context of Turkey}

\author{
Öğr. Gör. Fatma Nalbant \\ Artvin Çoruh Üniversitesi, Yusufeli Meslek Yüksekokulu \\ fatmanalbant@artvin.edu.tr \\ (ORCID: 0000-0003-2588-1804) \\ Dr. Öğr. Üyesi Tuğrul Korkmaz \\ Aksaray Üniversitesi, İktisadi ve İdari Bilimler Fakültesi \\ tugrulkorkmaz@aksaray.edu.tr \\ (ORCID: 0000-0001-5497-6314)
}

\begin{abstract}
Özet
Feminizm, kadının erkek karşısındaki konumunu daha sağlam zeminde inşa etmek ve kadın-erkek arasındaki eşitsizliğin ortadan kalkmasını sağlayabilmek amacıyla ortaya çıkmıştır. Bu anlamda 18. ve 19. yüzyıldan itibaren kadın hareketi olarak birçok alanı etkilemiş, kadının özel kamusal alandaki yerini sorgulamış ve dönüştürmüştür. Kadınların oy hakkı, yönetime katılma hakkı, tüm mesleklere girme ve bunların sağlanması için eğitim hakkı adına mücadele edilen birinci dalga feminist hareket ile ikinci dalga feminist hareketin, devlet yönetimi, iş yaşamı ve eğitim gibi pek çok alanı toplumsal cinsiyet kavramı ile şekillendirdiği görülmektedir. Bu bağlamda feminist teori temelinde hazırlanan çalışmada toplumsal cinsiyet eşitliğinin toplumsal, siyasal ve ekonomik alanlarda yaratılması üzerinde durulmuş ve Türkiye bağlamında kadınların siyasi temsil, istihdam ve eğitim alanlarındaki mevcut durumları istatistiksel verilerden yararlanarak betimlenmeye çalışılmıştır.
\end{abstract}

Anahtar Kelimeler: Feminizm, Toplumsal Cinsiyet, Türkiye.

Jel Sınıflandırması: J16

\begin{abstract}
Feminism arose in an attempt to build the women's position against men on more substantial basis, and to make it possible to remove the inequality between womenmen. Therefore, it has influenced several areas as women's movement, interrogated
\end{abstract}

\footnotetext{
${ }^{1} \mathrm{Bu}$ çalışma, 17-18-19 Nisan tarihinde düzenlenen Artvin Uluslararası Sosyal Bilimler Kongresi (AICOSS 2019)'nde özet bildiri olarak sunulmuştur.
} 
and transformed women's place both in private and public areas since the 18th and 19th centuries. It is observed that with the first wave feminist movement which struggled for women's right of vote, right of participation in administration, going into all professions, and naturally right of education, and with the second wave feminist movement; the govenment, business area, education and more areas have been shaped by the concept of social gender. Within this context, in the study made on the basis of feminist theory, providing social gender equality in social, political and economical areas has been emphasized; and women's current position in the areas of political representation, employment and education within the context of Turkey has been described by making use of statistical data.

Key Words: Feminism, Social Gender, Turkey.

JEL Classification: J16

\section{GíRIŞ}

Feministler, kadın ve erkek arasındaki farklılıkların küçük olduğunu ve her iki cinsiyetin de özelliklerini üstünde taşıdığını savunmaktadırlar. Feminist düşünceye göre erkek ve kadınlar cinsiyetlerine göre değil, birer birey-kişi olarak değerlendirilmelidir. Dolayısıyla feminizmin amacı toplumsal cinsiyetsiz "kişiliğe" ulaşmaktır. Bu anlamda biyolojik cinsiyetten ayrı bir toplumsal cinsiyet tesis etmek, feminist teori için önem taşımaktadır (Heywood, 2010). Feminizm, toplumsal cinsiyet ayrımcılı̆̆ına, toplumsal yaşamın tüm yönlerinde kadınların yaşadıkları sorunlara ve ikincil konumda görülmelerine çözüm yolları bulmayı amaçlamaktadır. Feminist teori temelinde hazırlanan çalışmada toplumsal cinsiyet eşitliğinin toplumsal, siyasal ve ekonomik alanlarda yaratılması üzerinde durulmuştur. Çalışmanın amacı; feminist teori çerçevesinde toplumsal cinsiyet eşitliği konusunu istatistiksel verilerden hareketle Türkiye özelinde genel bir çerçeve ile sunmaktır. Bu çalışmada ilk olarak hem politik bir ideoloji hem de bir toplumsal hareket olarak tanımlanan feminizm ve toplumsal cinsiyet kavramı tanımlanmıştır. Ardından Türkiye'de toplumsal cinsiyet eşitliği üzerine yapılan ulusal düzenlemeler içerisinde anayasa, belediye kanunları, eğitim hukuku ve iş hukukunda yer alan düzenlemelere yer verilmiştir. Son olarak ise Türkiye' de toplumsal cinsiyet eşitliği ekseninde eşitlikçi/eşitliksizci illerin genel görünümü, genel-yerel seçimlerde kadın temsili oranları, kadın istihdam 
oranları ve kadınların okur-yazarlık durumları güncel veriler ile ortaya konularak, mevcut durum betimlenmiştir.

\section{KAVRAMSAL OLARAK FEMINIZMM VE GELIŞ̧iMI}

Feminizm veya feminist teori kavramına ilişkin literatürde birçok farklı tanım bulunmaktadır. Bu anlamda öncelikle feminizm kelimesinin kökü incelendiğinde Latince'de kadın anlamına gelen "femina” sözcüğünden türemiştir (Sevim, 2005). Kavram, "güven, namus ve özgürlük" anlamına gelen "fe" ve eksik anlamına gelen "minis" sözcüğünden oluşmaktadır (Bayram, 2016). Bat1 dillerinin kökeni oluşturan Latincedeki bu kavramsallaştırma dahi aslında feminist teorinin çıkış noktasını oluşturabilir. Zira "feminus" namusu ve özgürlügü olmayan, "güvenilmez"i niteleyen bir anlamı halihazırda "kadının" içinde barındırmaktadır. Feminist düşünce ilk olarak 18. yüzyılda İngiltere' de filizlenmiş, 20. yüzyılda ise modern anlamda siyasi bir terim olarak kendine yer bulmuştur. Ortaya çıtığı günden bugüne feminizmin genel olarak, kadın hareketleri ve kadının sosyal statüsünü geliştirme çabasıyla ilişkilendirildiği görülmektedir (Heywood, 2010). Feminizm kelimesinin yaratıcısı Charles Fourier 1820 y1lında kaleme aldığı Doğadan Aşk Dünyasına adlı eserinde cinsiyete dayalı hiyerarşik iş bölümü üzerine "harmoni (toplumsal düzen), bizlerin kadınları mutfaklara ve ocakların başına hapsetme ile sağlanamaz. Doğa her iki cinsiyeti de eşit bir biçimde bilime ve sanata yetenekle donattı" görüşünü ifade etmiştir. Fourier’i ilgilendiren tek şey çoktan vadesi gelen cinsiyetlerin eşit haklarıdır (Notz, 2018).

Feminizm kısaca, kadınların cinsiyet temelli yaşamış oldukları zorlukları ortaya koyan ve bu zorlukları sınıf, ırk ve ulus gibi unsurlarda ele alan bir bilim alanı olarak tanımlanmaktadır (Sevim, 2005). Feminizm kavramının kökeni yeni olmasına karşın, Eski Yunan ve Çin medeniyetlerinde feminist görüşlerin ortaya çıktığı görülmektedir. Christine de Pisan 1405'te İtalya'da yayınlanan Hanımefendiler Şehrinin Kitabı ile Orta çağ'da kadınların ezilmesine karşı tepkisini ortaya koymuştur. Ancak, bu tepkinin bilinçli bir başkaldırıya dönüşümü 17. ve 18 yüzyıllarda olmuştur (Örs, 2016). Feminizm ideolojisinin tarihsel ön koşullarına bakıldığında ise; feodalizmin 
ve kapitalizmin gelişmesi ile toplumdan arka planda tutulan bir sosyal grup olarak hisseden orta sınıf kadınların çalışmaları ortaya çıktığı görülmektedir. Yeni burjuva sınıfının soyut farklılıkları dikkate almayan özgürlük ve eşitlik anlayışına karşı kadınlar da bu hakları talep etmeye başlamışlardır (Örs, 2016 ). 18. ve 19. yüzyıldan itibaren feminizm, birçok alanı etkilemiş, kadının özel ve kamusal alandakini yerini sorgulamış ve dönüştürmüştür.

Fransız Devrimi'nin temeline tepki olarak kalem alınmış olan Mary Wollstonecraft' in "Vindication of the Rights of Women (Kadin Haklarinin Savunması, [1792] 1967)" isimli eseri ilk modern feminizm çalışması olarak kabul edilmektedir. 19. yüzyılın ortalarına doğru kadın hareketi kapsamında ilk olarak, kadının seçme hakkı için kampanya yürütülüp esin kaynağı olarak erkeklere oy hakkı verilmesinin genişletilmesi gösterilmektedir. Bu dönem genellikle, "ilk feminizm dalgasl" olarak isimlendirilmektedir. Birinci dalgada kadınların erkeklerle aynı yasal ve siyasi haklara sahip olması talebi ön plana çıkmıştır (Heywood, 2010). Kadınların, seçimlerde oy kullanma hakkından yönetime katılma hakkına, eğitim ve meslek edinme hakkına kadar mücadele edilen birinci dalga feminist hareket, "devlet yönetiminde görev alınması, iş yaşamı, eğitim" gibi pek çok alan toplumsal cinsiyet kavramıyla şekillenmiştir (Aktaş, 2013). Birinci Dalga Feministlerinin çalışmaları neticesinde en önemli vatandaşlık haklarından biri olan seçme hakkı birçok ülkede yaygınlaşmıştır (ABD 1920, İngiltere 1928, Fransa 1940, İsveç 1970, Avustralya 1890 ve Türkiye 1934) (Örs, 2016). İkinci Dalga Feminizm ise; 1960’l1 ve 1970’li yıllarda ortaya çıkmıştır. İkinci Dalgada yer alan feministler özellikle cinsiyet ayırımcılığının kaldırılması konusunda toplumun her kesimine yönelik yoğun eleştirilerde bulunmuşlardır. Dolayısıyla ikinci dalga feminist hareketlerin temel kavramı kadınların toplumda yer edindikleri konumun biyolojik farklılıklar ile ilgili olmadığını aksine her toplumda yer edinmiş cinsiyetçi ayırımlardan temellendirildiğini ifade eden "toplumsal cinsiyet" kavramıdır. Günümüzde de feminist çalışmalarda kadınların konumlarını değerlendirme noktasında "toplumsal cinsiyet" ve "bakım" kavramlarının ön plana çıktı̆̆ görülmektedir (Koray, 2011).

Açıklamalar neticesinde ifade edilebilir ki birinci dalga feminizm hareketinde kadınların da vatandaşlık haklarını elde etmesi amaçlanmışken, 
ikinci dalga feminizm hareketinde ise tek tip bir kadın hayatının olamayacağı, kadınların toplum ve iş hayatlarında yer alması gerekliliği ve bu durumun yalnız beyaz kadınlara ait bir sorun olmadığı savunulmuştur (Taş, 2016). Feminist teori bundan dolayı kendi içinde oldukça fazla farklı eğilim sergileyen feminist olguları doğurmuştur. Buradan hareketle her feminist olgunun da farklı bakış açıları, kadınları kısıtlayan, baskıya ve engellere maruz bırakılan güçlerin kaynağına göre değiştiği söylenebilir. Nihayetinde sınıfa, ırka, dine, etnisiteye cinsel yönelime dayanan farklılıkların merkeze alınması neticesinde farklı akımlar daha da belirginleşmektedir. Liberal Feministler; hak eşitliğine odaklanmış, radikal feministler; kadınların sadece cinsiyet açısından kadın olarak dünyaya gelmiş oldukları için erkek baskısını yaşadıklarını ifade etmişlerdir. Marksist feministler ise kadınlar arasında da sınıfsal farklılıkların bulunduğu bunların arka plana atıldığını dile getirmişlerdir (Giddens, 2008). Radikal feminist düşüncenin ortaya çıkışından itibaren feminizm fikirleri ve değerlerinin, daha farklı bir ideoloji yönünde geliştiği görülmektedir. Bu anlamda feminizm, akademik yazın içerisinde "toplumsal cinsiyet" konusunu önemli bir noktaya taşımıştır (Heywood, 2010).

\section{TOPLUMSAL CINSIYYET KAVRAMI}

İnsan hayatında bireysel ve toplumsal yaşamın temel belirleyici özelliklerini ve dayanaklarını oluşturan kategorilerden birini de cinsiyet oluşturmaktadır. Temelde, "cinsiyet" kişinin kadın ya da erkek olarak gösterdiği biyolojik özellikleri iken "toplumsal cinsiyet" ise "cinsiyetten farkl olarak toplumun verdiği roller, görevler ve toplumun bireyi nasıl gördüğü ile ilgili bir kavram olarak tanımlanmaktadır (T.C. Başbakanlık Kadının Statüsü Genel Müdürlüğü, 2008). Aslında diğer bir ifade ile cinsiyet kavramı biyolojik, toplumsal cinsiyet kavramı ise kültürel bir yapıyı tanımlanmaktadır. "Kadın veya erkek olma" olarak ifade edilen bu konuda Dökmen'in tanım ve tespitleri de yukarıda bahsedilenlere paralellik taşımaktadır. Dökmen cinsiyeti, "bireyin biyolojisine göre belirlenen demografik bir kategori" olarak, cinsiyet kültürünün içerisinde yer alan "toplumsal cinsiyet rolleri" kavramını ise; "geleneksel olarak kadınlarla ve erkeklerle ilişkili olduğu kabul 
edilen ve uygun görülen kişilik özellikleri ve davranışları (rolleri)" olarak ifade etmektedir (Dökmen, 2004).

Feministler toplumsal cinsiyet kavramına 1970'li y1llarda yeni bir anlam yükleyerek, cinsiyet ve toplumsal cinsiyet olguları arasında ciddi bir ayrım yapmaktadırlar. Bu anlamda biyolojinin bir kader olduğu fikrini reddetmektedirler. Feministlere göre "cinsiyet (sex)" erkek ve kadın arasındaki biyolojik doğal ve değiştirilemeyen farklılıklar olarak ifade edilmektedir. Feministlere göre "toplumsal cinsiyet (gender)" ise toplum tarafından erkek ve kadına biçilen rolleri ifade eden kültürel bir kavramdır. Feministler toplumsal cinsiyet ayrımlarının sosyal olmasının yanında siyasi temelli olduğunu vurgulamaktadırlar. Genel olarak feministler kadın ve erkek arasındaki farklılıkların küçük olduğunu ve her iki cinsin de özelliklerini üstünde taşıdığını savunmaktadırlar. Erkek ve kadınlar cinsiyetlerine göre değil bireyler olarak, "kişiler" olarak değerlendirilmelidir (Heywood, 2010).

Toplumsal cinsiyette eşitlik anlayışı ise firsatların "kaynakların ayrlmasl ve kullanımında, hizmetlerin elde edilmesinde, bireyin cinsiyeti nedeniyle ayrımcılık olmaması" anlamını taşımaktadır. (Akın'dan aktaran: Saraç, 2013). Çünkü cinsiyet ayrımcılığı her iki cinsiyeti de olumsuz etkileyebilmektedir. Toplumsal yaşamda kadın ve erkekten beklenen cinsiyet rollerine bakıldığında, oldukça farklılık gösterdiği görülmektedir. Ayrıca "Toplumsal Cinsiyet ve Kalkınma (Gender and Development - GAD)" yaklaşımı, kadınların arka plana itilmesinin sebebi olarak görülen ataerkil anlayış ile kadınların ekonomik şart ve sınıfsal durumlarının da sorgulanması gerekliliğine odaklanmaktadır. Bu anlayışa göre toplumsal cinsiyet ilişkileri davranış kalıpları ile toplumsal olarak yapılandırılmış oldukları için, istenildiğinde değiştirilebilecektir. $\mathrm{Bu}$ anlamda Toplumsal Cinsiyet ve Kalkınma yaklaşımı, toplumun farklı yönlerini biçimlendiren hususları anlamak üzere ekonomik ve siyasi hayata toplumsal organizasyonun bütüncüllüğ̈̈ açısından bakmaktadır (Yumuş, 2011).

Toplumsal cinsiyet sorunları dünyanın her bölgesinde yaşanabilen bir durumdur. Bu bağlamda düzenlemelerin eksik veya yetersiz olduğu, alınan birçok karara rağmen uygulamada devletlerin cinsiyet eşitliğinin sağlanmasında tam etkin olamadığı göze çarpmaktadır (Dünya Ekonomik 
Forumu, 2017). 2020 yılı aralık ayında yayınlanan "Küresel Cinsiyet Eşitliği Uçurum Raporu" unda 153 ülkenin cinsiyet eşitliğine ilişkin veriler sunulmuştur. Bu raporla oluşturulan "Küresel Cinsiyet Eşitliği Uçurumu Endeksi”, ekonomiye katılım ve firsat; eğitime katılım; sağlı ve sağ kalım ve siyasi güçlenme başlıkları altında dört temel gösterge çerçevesinde kadınlar ve erkekler arasındaki cinsiyet eşitsizliğini analiz etmektedir. Rapordaki endeksler ülkelerin gelişmişlik düzeylerine göre değil, toplumsal cinsiyet uçurumlarının sıralanması ile oluşturulmuştur. Bahsi geçen raporda 153 ülke arasında Türkiye 130. sırada yer alırken benzer coğrafi ve kültürel özellikler taşıyan bazı ülkelerin Türkiye'nin üstünde yer aldığı dikkat çekmektedir. Örneğin İsrail sıralamada 64., Tunus 124. ve Birleşik Arap Emirlikleri 120. sırada yer almaktadır (Global Gender Gap, 2020). 2006 ve 2020 y1llar1 "Dünya Ekonomik Forumu Küresel Cinsiyet Uçurumu" raporlarındaki Türkiye siralamaları Tablo 1'de gösterilmiştir.

Tablo1. 2006 ve 2020 Y11ı Dünya ekonomik forumu küresel cinsiyet uçurumu endeksine ilişkin bilgiler

\begin{tabular}{lcc}
\hline \multicolumn{1}{c}{ TÜRKIYE } & $\begin{array}{c}\mathbf{2 0 0 6} \\
\text { Siralama }\end{array}$ & $\begin{array}{c}\mathbf{2 0 2 0} \\
\text { Siralama }\end{array}$ \\
\hline Küresel Cinsiyet Eşitliği Sıralaması & 105 & 130 \\
Ekonomiye Katılım ve Fırsat & 106 & 136 \\
Eğitime Katılım & 90 & 113 \\
Sağlık ve Sağ kalım & 85 & 64 \\
Siyasi Güçlenme & 96 & 109 \\
Değerlendirmeye Alınan Ülke Sayısı & 115 & 153 \\
\hline
\end{tabular}

Kaynak: Global Gender Gap 2020, s.343.

Tablo 1 incelendiğinde raporun sonucuna göre Türkiye; katılım ve firsat kategorisinde 136.sırada, eğitim başarısı kategorisinde 113.sırada, sağlık ve sağ kalım kategorisinde 64.sırada ve siyasi güçlenme kategorisinde 109.sırada yer almaktadır. Rapor sonucu değerlendirildiğinde Türkiye'de toplumsal cinsiyet eşitsizliğinin, ortadan kaldırılması için düzenlemelerde yer alan politikaların uygulamada daha etkili düzeyde gerçekleştirilmesi gerektiği ifade edilebilir. Çalışmanın bu kısmında Türkiye'de ulusal düzenlemelerde toplumsal cinsiyet eşitliğine ilişkin maddelere yer verilecek sonrasında ise il 
ölçeğinde, siyaset, eğitim ve istihdam alanlarında toplumsal cinsiyet eşitliğinin var olup- olmadığı verilerden yararlanılarak değerlendirilmeye çalışılacaktır.

\section{TÜRKIYYE'DE ULUSAL DÜZENLEMELERDE TOPLUMSAL CINSIYYET EŞITLIİ̆İ}

Günümüzde uluslararası belgelerde, toplumsal cinsiyet eşitliğinin sağlanması ve kadınların ikinci plana atılan haklarının garanti altına alınması devletlerin sorumluluğuna verilmiştir (Turan, 2013). Bu anlamda günümüzde çeşitli ülkeler, ilk olarak insan haklarına saygılı olmaya ve kadın-erkek eşitliğine dikkat çeken demokratik anayasalar yapmaya önem vermişlerdir. Bu anlamda "toplumsal cinsiyete duyarlı bir anayasa; erkekler ve kadınlara aynı şekilde olmak üzere bütün vatandaşların onuruna saygının tesisini bir araya getiren demokratik ilkelerin benimsenmesini içeren bir anayasa" olarak tanımlanmaktadır (Eroğlu, 2011). Türkiye'de toplumsal cinsiyet eşitliğinin ana plan ve politikalara yerleştirmek için çeşitli alanlarda hukuki adımlar atılmıştır. Bunların başında, eğitimin tek sistem altında toplandığ 1 ve kadınlarla erkeklere eşit eğitim imkânların sağlandığı 1924 yılında kabul edilen Tevhidi Tedrisat Kanunu gelmektedir. Ayrıca, önemli bir diğer hukuki düzenleme ise Türk kadınlarına 1930'da yerel, 1934'te ise genel seçimlerde seçme ve seçilme hakkının verilmesidir (Turan, 2013). Türkiye'de başta anayasa olmak üzere tüm yasalarda kadın erkek fırsat eşitliğinin sağlanmasına yönelik düzenlemeler yapıldığ

$\mathrm{Bu}$ bağlamda çalışmada ele alınan mevcut veriler ile ilişkili olarak "Anayasa", "Belediye Kanunları", "İş Kanunu” ve "Eğitim Kanunu” kadınerkek eşitliğine ilişkin yer alan bazı düzenlemeler aşağıda sıralanmıştır:

- 5 Aralık 1934 tarihinde anayasanın 11. maddesinde yapılan değişiklikle kadınlara seçilme hakkı tanınmış ve 1982 anayasasında da milletvekili seçilecekler için cinsiyet ayrımı yapılmamıştır.

- 2001 yılında anayasanın 41. maddesinde yer alan; "Aile Türk toplumunun temelidir" ifadesinden sonra "ve eşler arasında eşitliğe dayanır" hükmü eklenerek kadın erkek eşitliği güçlendirilmeye çalışı1mıştır. 
- Anayasanın 10. Maddesi'nde "herkesin, dil, ırk, renk, cinsiyet, siyasi düşünce, felsefi inanç, din, mezhep ve benzeri sebeplerle ayrım gözetilmeksizin kanun önünde eşittir" maddesine $\mathrm{AB}$ müktesebatına uyum çerçevesinde 2004 yılında yapılan bir değişiklikle "Kadınlar ve erkekler eşit haklara sahiptir. Devlet bu eşitliğin yaşama geçmesini sağlamakla yükümlüdür" ifadesi eklenmiştir. Toplumsal cinsiyet eşitliğini gözeten uygulamaların devlet tarafından sağlanacağı vurgulanmıştır. Aynı yıl anayasanın 90. maddesine ise şu ifade eklenmiştir: "Usulüne göre yürürlüğe konulmuş temel hak ve özgürlüklere ilişkin milletlerarası anlaşmalarla ulusal kanunların aynı konuda farklı hükümler içermesi durumunda çıkabilecek ihtilaflarda milletlerarası anlaşma hükümleri esas alınır".

- 2010 y1lında 10. maddenin ikinci fikrasının sonuna: “...bu maksatla alınacak tedbirler, eşitlik ilkesine aykırı olarak yorumlanamaz" ifadesi eklenerek eşitlik ilkesi bir kez daha vurgulanmıştır.

- 7 Mayıs 2010 tarih ve "5982 sayll Türkiye Cumhuriyeti Anayasasının Bazı Maddelerinde Değişiklik Yapılması Hakkında Kanun” ile anayasada değişiklik yapılarak "Herkes, Anayasada güvence altına alınmış temel hak ve özgürlüklerinden, Avrupa İnsan Hakları Sözleşmesi kapsamındaki herhangi birinin kamu gücü tarafindan ihlal edildiği iddiasiyla Anayasa Mahkemesine başvurabilir" hükmü düzenlenmiştir. Bu düzenlemeler sonucunda, cinsiyet ayrımcıllğının yaşanması durumunda Anayasa Mahkemesine bireysel başvuru yolu açılmıştır.

- 5393 sayıl1 Belediye Kanunu'nun 14.maddesine, 2012 yılında 6360 Sayılı Kanun ile "büyükşehir belediyeleri ile nüfusu 100.000'in üzerindeki belediyeler, kadınlar ve çocuklar için konukevleri açmak zorundadır" ifadesi eklenmiştir.

- Çalışma hayatını düzenleyen 4857 sayılı İş Kanunu'nda çalışma yaşamında kadın erkek eşitliğinin sağlanması yönünde 2003 yılında önemli değişiklikler yapılmıştır. 4857 sayılı İş Kanunu 5.maddesinde "İs ilişkisinde dil, ırk, renk, cinsiyet, engellilik, siyasal düşünce, felsefi inanç, din ve mezhep ve benzeri sebeplere dayalı ayrım 
yapılamaz" ve 18.maddenin 3 fikrasının d bendinde yer alan "Irk, renk, cinsiyet, medeni hal, aile yükümlülükleri, hamilelik, doğum, din, siyasi görüş ve benzeri nedenler" ifade ile iş yaşamında, cinsiyet eşitliğine önem verildiği maddelerde görülmektedir. 4857 sayılı İş Kanunu'nun kabul edilmesi, insan hakları açısından mevcut eksiklikleri gidermede önemli bir ilerleme olarak görülmektedir. Ayrıca anayasada yer alan "Çalışma ve Sözleşme Hürriyeti" başlıklı 48. madde de kadın ve erkek ayrımı olmaksızın herkesin dilediği alanda çalışma ve sözleşme hürriyetine sahip olduğu belirtilmektedir.

- Eğitim hakk1 ise anayasanın 42. maddesinde; "kimse, eğitim ve ögrenim hakkından yoksun bırakllamaz ve ilköğretim, kız ve erkek bütün vatandaşlar için zorunludur ve devlet okullarında parasızdır" şeklinde ifade edilerek başta anayasa olmak üzere, Millî Eğitim Temel Kanunu ile İlköğretim ve Eğitim Kanunu'nda vurgulanmaktadır.

Son yıllarda kalkınma sürecinin en önemli unsurlarından birini oluşturan toplumsal cinsiyet eşitliğinin sağlanması, toplumsal yaşamın her alanında önem kazanmış ve dolayısıyla toplumsal cinsiyet eşitliği konusu planlar ve programlarda yerini almıştır. Türkiye'de Kalkınma Planları'nda kadının güçlendirilmesi ve toplumsal cinsiyet eşitliğine yönelik düzenlemeler bulunmaktadır. Kalkınma planları incelendiğinde kadın konusuna ayrı bir başlık halinde yer verildiği görülmektedir. Bu anlamda Onuncu Beş Yıllık Kalkınma Planı'na bakıldığında ise kadınların eğitimin güçlendirilmesi, iş hayatına ve sosyal yaşama katılım seviyesinin yükselmesi ve kadınların işgücüne katılma oranının artırılmasına yönelik çalışmalar sonucunda firsat eşitliğinin sağlanmasında Türkiye'nin bu potansiyele sahip olduğu belirtilmektedir (www.sbb.gov.tr/kalkinma-planlari). Kadınların siyasal temsili, istihdam ve eğitim alanlarına yönelik olarak ayrı bir yer veren hukuki düzenlemeler, toplumsal cinsiyet eşitliğinin sağlanmasında önemli adımlar olarak değerlendirilmektedir.

\section{TÜRKIYE'DE TOPLUMSAL CINSIYYT EŞITLİĞININ GENEL GÖRÜNÜMÜ}


Çalışmanın bu bölümünde toplumsal cinsiyet eşitliğinin Türkiye özelinde il ölçeğindeki genel görünümü, kadınların siyasal temsili, istihdam ve eğitim alanlarındaki mevcut durumları istatistiksel verilerden yararlanılarak ortaya konulmuştur.

\subsection{Toplumsal Cinsiyet Eşitliğinin İl Ölçeğinde Durumu}

İllerin kadın erkek eşitliği konusundaki mevcut durumları ile yıllar arası toplumsal cinsiyet eşitliği karşısındaki durumlarını ortaya koymak için TEPAV tarafindan "81 İl İçin Toplumsal Cinsiyet Eşitliği Karnesi" hazırlanmıştır. Türkiye Toplumsal Cinsiyet Eşitsizliği Endeksinin il düzeyinde oluşturulmasında "sağlık, belediye meclisinde kadın-erkek oranlart, eğitim ve işgücüne katılım" olmak üzere dört temel göstergeden faydalanıldığı belirtilmektedir (Kavas, 2018). Bu bağlamda oluşturulan araştırma sonucuna göre Tablo 2'de en eşitsizliğin en az olduğu 10 il ve Tablo 3 ’te eşitsizliğin yüksek olduğu 10 il gösterilmiştir.

Tablo 2. 2015 ve 2017 Yılı verilerine göre eşitsizliğin en az olduğu ilk 10 il

\section{Toplumsal Cinsiyet Eşitsizliği $\quad$ Toplumsal Cinsiyet Eşitsizliği \\ Endeksi Sıralaması (2015) $\quad$ Endeksi Sıralaması (2017)}

\begin{tabular}{ccc}
\hline $\mathbf{1}$ & İstanbul & İstanbul \\
$\mathbf{2}$ & Bursa & Rize \\
$\mathbf{3}$ & Eskişehir & Ankara \\
$\mathbf{4}$ & Ankara & Bursa \\
$\mathbf{5}$ & Muğla & Tunceli \\
$\mathbf{6}$ & İzmir & Bolu \\
$\mathbf{7}$ & Yalova & Antalya \\
$\mathbf{8}$ & Bolu & Eskişehir \\
$\mathbf{9}$ & Düzce & Düzce \\
$\mathbf{1 0}$ & Kocaeli & Kocaeli \\
\hline
\end{tabular}

Kaynak: 2016 ve 2018 yılı "Karşılaştırmalarla 81 İl İçin Toplum Cinsiyet Eşitliği Karnesi”nden derlenmiştir (Kavas, 2018).

2015 yılına ait verileri kullanarak oluşturulan raporda, eşitsizliğin en az olduğu ilk 10 il sıralamasında İstanbul, Bursa, Eskişehir, Ankara, Muğla, İzmir, Yalova, Bolu, Düzce ve Kocaeli yer almaktadır. 2017 yılına ait verileri kullanarak oluşturulan rapora göre ise İstanbul tekrar ilk sırada yer alırken ardından Rize, Ankara, Bursa, Tunceli, Bolu, Antalya, Eskişehir, Düzce ve 
Kocaeli gelmektedir. Rize de y1llar itibariyle ciddi oranda iyileşme görülmektedir.

Tablo 3. 2015 ve 2017 Yılı verilerine göre eşitsizliğin en yüksek olduğu 10 il

\begin{tabular}{|c|c|c|}
\hline & $\begin{array}{l}\text { Toplumsal Cinsiyet Eşitsizliği } \\
\text { Endeksi Sıralaması (2015) }\end{array}$ & $\begin{array}{c}\text { Toplumsal Cinsiyet Eşitsizliği } \\
\text { Endeksi Sıralaması (2017) }\end{array}$ \\
\hline 72 & Bingöl & Ardahan \\
\hline 73 & Sivas & Siirt \\
\hline 74 & Aksaray & Kars \\
\hline 75 & Elâzı̆̆ & Bitlis \\
\hline 76 & Adiyaman & Iğdır \\
\hline 77 & Siirt & Muş \\
\hline 78 & Afyon & Niğde \\
\hline 79 & Niğde & Yozgat \\
\hline 80 & Yozgat & Afyon \\
\hline 81 & Muş & Ağrn \\
\hline
\end{tabular}

Kaynak: 2016 ve 2018 y1l "Karşılaştırmalarla 81 İl İçin Toplum Cinsiyet Eşitliği Karnesi”nden derlenmiştir (Kavas, 2018).

2015 y1lına ait verileri kullanarak oluşturulan raporda, eşitsizliğin en yüksek olduğu 10 il; Bitlis, Muş, Yozgat, Niğde, Afyon, Siirt, Adıyaman, Elazığ, Aksaray, Sivas ve Bingöl'dür. 2017 yılına ait verileri kullanarak oluşturulan raporda ise eşitsizliğin en yüksek olduğu Ağrı'yı, Afyon, Yozgat, Niğde, Muş, Iğdır, Bitlis, Kars, Siirt ve Ardahan izlemektedir.

"Sağllk, belediye meclisinde kadın-erkek oranlarl, eğitim ve işgücüne katılım" alanlarında yaşanan değişimler sonucunda 2015 yılı ve 2017 yılı il sıralamalarında farkl1l1klar olduğu görülmektedir. İllerin sıralamalarında kadınlarla ilgili her bir göstergede yaşanan farklılaşma, illerin sıralamasını değiştirmektedir. Yapılan çalışmaya göre değişimi en çok etkileyen göstergenin, kadınların belediye meclislerindeki temsil edilme oranlarıdır. Dolayısıyla sağlık, eğitim ve istihdam göstergelerinde yaşanan değişimin yanı sıra, kadınların belediye meclisindeki temsil edilme oranında yaşanan değişimler daha fazla etki yaratmaktadır (Kavas, 2018).

\subsection{Toplumsal Cinsiyet Eşitliğinin Siyasetteki Görünümü}

Yerel yönetimler halka en yakın birimler olarak; kadınların karar alma süreçlerinde yer almalarında önemli bir role sahiptir. Dolayısıyla, yerel düzeyde alınan kararlarda "kadın -erkek eşitliği" ne daha fazla dikkat çekilebilmesi için kadınların, yerel yönetimlerin karar organlarında yer alması 
son derece faydalı olabilir. Ancak, siyasal yaşama katılımının ilk basamağı olarak değerlendirilen yerel yönetimler de kadınların sınırlı bir şekilde yer aldıkları görülmektedir (Şahin, 2008). Türkiye'de kadınlar yerel yönetimlere seçme ve seçilme hakkını 1930 yılında elde etmiş olmasına karşın kadınların siyasete katılımı toplumsal cinsiyet eşitsizliğinden kaynaklanan olumsuzluklar neticesinde sınırlı olmaktadır. 2009 ve 2014 yerel seçim dönemleri itibariyle yerel yönetimlerde görev yapan kadın ve erkek seçilmişlerin sayıları Tablo 4'te gösterilmiştir.

Tablo 4. 2009-2014 yılları mahalli idarelerin seçilmiş görevlilerine ilişkin bilgiler

\begin{tabular}{lccc}
\hline 2009 & Kadın & Erkek & Toplam \\
\hline Belediye Başkanı & 26 & 2.922 & 2.948 \\
Belediye Meclis Üyesi & 1.340 & 30.450 & 31.790 \\
İl Genel Meclis Üyesi & 110 & 3.269 & 3.379 \\
Köy Muhtarı & 65 & 34.210 & 34.275 \\
Köy İhtiyar Heyeti & 329 & 137.848 & 138.177 \\
Mahalle Muhtarı & 429 & 18.178 & 18.607 \\
Mahalle İhtiyar Heyeti & 1.409 & 71.174 & 72.583 \\
Toplam & $\mathbf{3 7 0 8}$ & $\mathbf{2 9 8 . 0 5 1}$ & $\mathbf{3 0 1 . 7 5 9}$ \\
\hline $\mathbf{2 0 1 4}$ & Kadın & Erkek & Toplam \\
\hline Büyükşehir Belediye Başkanı & 3 & 27 & 30 \\
Büyükşehir İlçe Bel. Başk. & 23 & 496 & 519 \\
Belediye Meclis Üyesi & 2.198 & 18.300 & 20.498 \\
İl Belediye Başkanı & 1 & 50 & 51 \\
İlçe ve Belde Belediye Başkanı & 13 & 784 & 797 \\
İl Genel Meclis Üyesi & 60 & 1.191 & 1.251 \\
Köy Muhtarı & 58 & 18.085 & 18.143 \\
Köy İhtiyar Meclis Üyesi & 1.007 & 79.689 & 80.696 \\
Mahalle Muhtarı & 622 & 31.013 & 31.635 \\
Mahalle İhtiyar Heyeti Üyesi & 3.419 & 134.362 & 137.781 \\
Toplam & $\mathbf{7 . 4 0 4}$ & $\mathbf{2 8 3 . 9 9 7}$ & $\mathbf{2 9 1 . 4 0 1}$ \\
\hline Kaynak: YSK, Mahalli İdarel geñ
\end{tabular}

Kaynak: YSK, Mahalli İdareler genel seçim sonuçlarına göre hazırlanmıştır, 2018.

Tablo 4'te 2014 yıll yerel seçim sonuçları incelendiğinde il genel meclis üyeliği sayısının erkeklerde 1191, kadınlarda ise 60 olduğu görülmektedir. Büyükş̧ehir belediye başkanlığı erkeklerde 27, kadınlarda ise 3 'tür. Belediye başkanlığ erkeklerde 1314, kadınlarda ise 37 'dir. Belediye meclis üyeliği erkeklerde 18 bin 300 iken kadınlarda 2 bin 198'dir. 2009 yılında 1 kadın büyükşehir ilçe belediye başkanı, 2014 yılında yapılan seçimde ise 3 kadın büyükşehir belediye başkanı ve 23 kadın büyükşsehir ilçe belediye başkanı seçilmiştir. Oransal olarak bakıldığında 2009 yılında kadın belediye başkan 
temsili oran $1 \% 0.8$ 'dir. 2014 yılında ise belediye sayısında bir düşüş yaşandığ 1 ve kadın belediye başkan temsilinin arttığ görülmektedir. Bu noktada 2014 yılında kadın belediye başkan temsil oranının \%2.86'ya yükselmesi, belediye sayısının azalması ile de ilişkilendirilebilir. Yıllar itibari ile belediye başkanlığında kadın erkek oranları karşılaştırıldığında, Türkiye'de kadın belediye başkan sayısında artış yaşandığı görülmektedir ancak bu sayı erkek belediye başkan sayısına göre oldukça düşüktür.

Kadın belediye meclis üyesi temsil oran 2009 yılında \%4.21 ve 2014 yılında \%10.7'dir. Kadın il genel meclis üyesi temsil oranı ise 2009 yılında $\% 3.25$ ve 2014 y1lında \%4.79'dur. Tablo 5'teki belediye meclis üyesi ve il genel meclis üyesi sayılarına bakıldığında buradaki kadın temsil oranının, erkek egemenliğinin gözle görülür varlığına rağmen, belediye başkanlığ 1 ile karşılaştırıldığında daha fazla olduğu ifade edilebilir. Kadın temsilinde ise köy ve mahalle yönetimlerindeki farklılık belirgin bir şekilde görülmektedir. 2009-2014 yılları incelendiğinde kadınların köy muhtarlığındaki temsil sayısının mahalle muhtarlığına göre düşük olduğu görülmektedir. 2014 yılı verilerine göre 680 kadın muhtardan yalnızca 58'i köy muhtarlığında, 622'si ise mahallelerde görev almıştır. Elde edilen veriler 1şı̆̆ında kadınların sorunlarına çözüm bulabilmeleri için siyasete katılımları önemlidir, ancak kadınların temsil oranının düşük olduğu görülmektedir. Tablo 5'te ise 31 Mart 2019'da yapılan mahalli idareler seçim sonuçlarına ilişkin bilgiler gösterilmiştir.

Tablo 5. 2019 Yılı mahalli idarelerin seçilmiş görevlilerine ilişkin bilgiler

\begin{tabular}{lccccc}
\hline $\mathbf{2 0 1 9}$ & Kadın & Oran $(\%)$ & Erkek & Oran $(\%)$ & Toplam \\
\hline Büyükşehir Belediye Başkanı & 3 & 10 & 27 & 90 & 30 \\
Büyükşehir İlçe Belediye Başkanı & 25 & 5 & 494 & 95 & 519 \\
Belediye Meclis Üyesi & 2.284 & 11 & 18.461 & 89 & 20.745 \\
İl Belediye Başkanı & 1 & 2 & 50 & 98 & 51 \\
İlçe ve Belde Belediye Başkanı & 12 & 2 & 776 & 98 & 788 \\
İl Genel Meclis Üyesi & 48 & 4 & 1.223 & 96 & 1.271 \\
Köy Muhtarı & 115 & 1 & 18.081 & 99 & 18.196 \\
Mahalle Muhtarı & 970 & 2 & 31.049 & 98 & 32.019 \\
Köy İhtiyar Meclis Üyesi & 1.007 & 1 & 79.689 & 99 & 80.696 \\
Mahalle İhtiyar Heyeti Üyesi & 3.418 & 2 & 134.362 & 98 & 137.780 \\
Toplam & 7.883 & 3 & 284.212 & 97 & 292.095 \\
\hline
\end{tabular}


Kaynak: YSK, İIGM, 2019.

Son dönemler olarak 2014- 2019 y1lı mahalli idareler genel seçim sonuçları kıyaslandığında ise seçilmiş kadın sayısının 7.404'ten 7.883'e çıktığı, 479 katılımla artış yaşandığı görülmektedir. Genel olarak yerel seçimler sonuçlarına ilişkin bilgiler kadınların katılım oranları açısından değerlendirildiğinde; 2009 y1lı yerel seçimlerinde oran \%0,9, 2014 y1l \%2,9 ve 2019 yerel seçimlerinde ise \%7,89 oranlarında olduğu görülmektedir. Bu noktada Şahin'in (2011) ifade ettiği üzere; kadınların yerel siyasete katılımının yüksek olması ulusal seçimlerde yer almalarını etkilemektedir. İlk olarak yerel siyasette yer alan kadının kendine olan güveni gelmekte ve sonrasında ulusal düzeyde siyasete katılımı daha çok önemsemektedir. Yerel siyasetteki kadın sayısının artması aynı zamanda diğer kadınlar için de bir hedef teşkil ettiğinden gelecek nesillerdeki katılım oranında da bir artış sağlayacağı öngörüsünde bulunulabilir. Dolayısıyla ulusal düzeyde siyasette katılımın mevcut durumunun ortaya konulabilmesi için Tablo 6'da 19832018 seçim yıllarına göre milletvekili sayıları gösterilmiştir:

Tablo 6. 1983-2018 Yılı seçim yıllarına göre milletvekili sayılarına ilişkin bilgiler

\begin{tabular}{rcccc}
\hline Seçim Yılı & Erkek & Kadın & \% & Toplam \\
\hline $\mathbf{1 9 8 3}$ & 387 & 12 & 3,01 & $\mathbf{3 9 9}$ \\
$\mathbf{1 9 8 7}$ & 444 & 6 & 1,33 & $\mathbf{4 5 0}$ \\
$\mathbf{1 9 9 1}$ & 442 & 8 & 1,8 & $\mathbf{4 5 0}$ \\
$\mathbf{1 9 9 5}$ & 537 & 13 & 2,4 & $\mathbf{5 5 0}$ \\
$\mathbf{1 9 9 9}$ & 527 & 23 & 4,2 & $\mathbf{5 5 0}$ \\
$\mathbf{2 0 0 2}$ & 526 & 24 & 4,4 & $\mathbf{5 5 0}$ \\
$\mathbf{2 0 0 7}$ & 500 & 50 & 9,1 & $\mathbf{5 5 0}$ \\
$\mathbf{2 0 1 1}$ & 471 & 79 & 14,4 & $\mathbf{5 5 0}$ \\
$\mathbf{2 0 1 5}(\mathbf{0 7 . 0 6})$ & 452 & 98 & 17,8 & $\mathbf{5 5 0}$ \\
$\mathbf{2 0 1 5}(\mathbf{0 1 . 1 1})$ & 469 & 81 & 14,7 & $\mathbf{5 5 0}$ \\
2018 & 496 & 104 & 17,3 & 600 \\
\hline
\end{tabular}

Kaynak: YSK genel seçim sonuçlarına göre hazırlanmıştır, 2018.

Türkiye'de özellikle son y1larda ulusal ve yerel seçimlerde mecliste daha fazla kadın katılımcının yer almasına ilişkin ciddi girişimlerin olduğu görülmektedir. Tablo 6'ya bakıldığında son dönemlerde kadın temsil oranında önemli artış yaşandığ 1 ifade edilebilir. Ancak Türkiye nüfusunun yarısını 
kadınlar oluşturmaktadır. Bu anlamda 2018 yılı toplam içindeki \%17,3 lük bir temsilin kadın nüfusu içerisinde yeterli olmadığı vurgulanabilir. Genel bir değerlendirme yapıldığında ise yıllar itibari ile kadınlara seçme ve seçilme hakkının verilmesinde siyasette yaşanan değişimlerin etkili olduğu görülmektedir. 2002 yılı sonrası siyasette yaşanan değişim ile kadın temsilinde artış yaşandığı ifade edilebilir.

Bunun yanında siyasete aktif katılım noktasında kadınların son zamanlarda daha istekli olduğu da görülmektedir. Kadınların istekli olmalarında ise bazı faktörler etkili olmaktadır. Bunlar (kadem.org.tr): “Aday olunan bölgede bilinen bir aileye mensup olma, böyle bir ailenin kızı, gelini veya eşi olma, Doğu Bölgesinde aşiret mensubu olma ve kadınların parti teşkilatlarından geliyor olmaları da adaylık sürecinde etkili olmaktadır". Partilerin aday listeleri incelendiğinde başvuran kadın sayısında önemli bir artış olduğu görülmekle birlikte mecliste kadın temsilci sayısının yeterli düzeyde olmadığ tablodaki veriler göstermektedir. 2018 y1lı Yüksek Seçim Kurulu 27. Dönem Milletvekili Seçimi sonuçlarına göre TBMM'de grubu bulunan siyasi partilerin listelerde kadınların katılımının sağlanacağını dile getirilmesine rağmen, listelerdeki kadın aday temsili HDP'de 38,81, AK Parti'de \%17,97 CHP'de \%12,33, MHP'de 8,16 ve İyi Parti'de 6,98 düzeyindedir (www.ysk.gov.tr). Kadınların yetersiz düzeyde temsilini ele alan çalışmalar, bu durumun başlıca nedenleri olarak ataerkil kültür ve kadın-erkek eşitsizliği olmak üzere iki soruna dikkat çekmektedir. Kadınların yetersiz temsilini açıklamakta kullanılan birinci sorun "ataerkil kültür ve ataerkil aile yapısı" dır. Bu durum toplumsal kültürün ve bu bağlamda siyasetin erkek egemen bir şekilde kurulmuş olması olarak ifade edilmektedir. Kadınların yetersiz temsiline ilişkin gösterilen ikinci sorun ise, kadın-erkek eşitliğidir (Negiz vd. 2008'den aktaran: Arıkboğa, 2009).

\subsection{Toplumsal Cinsiyet Eşitliğinin İstihdam Alanındaki Görünümü}

Feminist kuramda istihdamda tartışılan konulardan biri de ataerkil bir düzen içinde kadının çalışma hayatında yer almasıdır. Ataerkil sistemde erkeğin güçlü kılınması kadınların iş hayatında yaşadıkları baskıyı arttırmıştır. Bunun sonucunda kadınların ev hayatında yaşam alanı oluşturmalarını 
sağlamıştır. Bu bağlamda toplumsal cinsiyet temelli kadın erkek arasındaki iş bölümünün ataerkil düzenin kullarını belirlediğini (Özçatal, 2011) ve kadın ve erkek mesleklerinde bir ayrışmayı ortaya koyduğu da ifade edilebilir. Ayrıca toplumsal yapı gözlemlendiğinde görülmektedir ki kadınların çalışma hayatı birçok nedenle kesintiye uğramaktadır. Bu nedenlerin başında kuşkusuz çocuk ya da aile büyüklerine bakma gelmektedir. $\mathrm{Bu}$ gibi nedenler kadınların çalışma yaşamındaki deneyimlerini azaltmakta ve kadınların belli alanlarda düşük ücret ile çalışmalarına neden olmaktadır (Kapucu, 2008).

Tablo 7'de 2017-2019 yılı verilerine göre kadınların iş hayatına katılımı gösterilmektedir:

Tablo 7. 2017 ve 2019 Kadın - erkek istihdamına ilişkin bilgiler

\begin{tabular}{|c|c|c|c|c|c|c|}
\hline & \multicolumn{3}{|c|}{2017 YILI } & \multicolumn{3}{|c|}{2019 YILI } \\
\hline & Kadın & Erkek & Toplam & Kadın & Erkek & Toplam \\
\hline İş Gücü & 10.287 & 21.503 & 31.790 & 10.723 & 22.261 & 33.180 \\
\hline $\begin{array}{l}\text { İş Gücüne } \\
\text { Katılım Oranı }\end{array}$ & $\% 33,80$ & $\% 72,10$ & $\% 52,80$ & $\% 35,0$ & $\% 73,2$ & $\% 53,9$ \\
\hline İstihdam Oranı & $\% 29,30$ & $\% 65,80$ & $\% 47,30$ & $\% 28,90$ & $\% 64,20$ & $\% 46,30$ \\
\hline İşsizlik Oranı & $\% 12,60$ & $\% 8,80$ & $\% 10,30$ & $\% 17,6$ & $\% 12,3$ & $\% 14,0$ \\
\hline
\end{tabular}

Kaynak: 2017 ve 2019 TÜİK işgücü istatistik verilerine göre hazırlanmıştır, 2019.

Tablo 7 oransal olarak değerlendirildiğinde 2017 y1lında \%29,30 olan kadın istihdamı oran 2019 yılında \%28,90'a düşmüştür. 2017 yılında 15 yaşın üzerindeki toplam nüfus içerisinde istihdam oranı erkeklerde $\% 65,80$ olmasına rağmen kadınlarda bu oran \%29,3 seviyesindedir. Kadınların 2019 yılı işgücüne katılma oranına bakıldığında ise 2017 yılına göre \%1,20 puanlık artış ile \%35,0'a yükselmiş olduğu görülmektedir. Tablodaki veriler genel olarak karşılaştırıldığında iyileşmeler yaşandığı görülmekle birlikte kadın istihdam oranında \%4,4'lük azalışın gerçekleşmesi ayrıca kadın işsizlik oranında \%5,0 düzeyinde artışın yaşanması kadın erkek eşitliği sorununun varlığını ortaya koymaktadır. İşgücü istatistikleri kıyaslandığında bu oranlarda olumlu yönde artışların olduğu ancak bu artışların çok düşük düzeyde gerçekleştiği görülmektedir. $\mathrm{Bu}$ durum, kadınların firsat ve olanaklardan faydalanma konusunda hala yeterli düzeye ulaşılamadığının göstergesi olarak değerlendirilebilir. Türkiye'de ekonomik büyüme için 
istihdam oranının yükseltilmesi önemli bir şarttır. Bunun gerçekleştirilebilmesi ise kadınların istihdama katılımının arttıılması ile sağlanabilir.

\subsection{Toplumsal Cinsiyet Eşitliğinin Eğitim Hayatındaki Görünümü}

Türkiye'de kadınların eğitim durumları bazı istatistiklerle ele alınmaktadır. 2014-2018 yılı verilerine göre, Türkiye nüfusunun 15 ve yukarı yaş grubunda öğrenim düzeyi ve cinsiyete göre dağılımı Tablo 8'de gösterilmektedir:

Tablo 8. 2014-2018 Yılları nüfusun 15 ve yukarı yaş grubunda öğrenim düzeyi ve cinsiyete göre dağılımı

\section{$\begin{array}{lll}\text { GENEL TOPLAM OKURYAZAR DEĞILL OKURYAZAR } & \text { OKL }\end{array}$}

\begin{tabular}{|c|c|c|c|c|c|c|c|c|c|}
\hline YIL & $\mathbf{E}$ & $\mathbf{K}$ & $\mathbf{T}$ & $\mathbf{E}$ & $\mathbf{K}$ & $T$ & $\mathbf{E}$ & $\mathbf{K}$ & $\mathbf{T}$ \\
\hline 2014 & $\begin{array}{c}29.092 . \\
191\end{array}$ & $\begin{array}{c}29.292 . \\
049\end{array}$ & $\begin{array}{c}58.38 \\
240\end{array}$ & $\begin{array}{l}430 . \\
782\end{array}$ & $\begin{array}{c}2.191 \\
302\end{array}$ & $\begin{array}{c}2.622 . \\
084\end{array}$ & $\begin{array}{c}28.226 . \\
604\end{array}$ & $\begin{array}{c}26.648 . \\
539\end{array}$ & $\begin{array}{c}54.875 . \\
143\end{array}$ \\
\hline 2015 & $\begin{array}{c}29.555 \\
739\end{array}$ & $\begin{array}{c}29.743 . \\
940\end{array}$ & $\begin{array}{c}59.29 . \\
679\end{array}$ & $\begin{array}{l}417 . \\
064\end{array}$ & $\begin{array}{c}2.166 \\
887\end{array}$ & $\begin{array}{c}2.583 \\
951\end{array}$ & $\begin{array}{c}28.863 . \\
360\end{array}$ & $\begin{array}{c}27.297 . \\
788\end{array}$ & $\begin{array}{c}56.161 . \\
148\end{array}$ \\
\hline 2016 & $\begin{array}{c}29.999 . \\
598\end{array}$ & $\begin{array}{c}30.202 . \\
960\end{array}$ & $\begin{array}{c}60.20 \\
558\end{array}$ & $\begin{array}{c}384 . \\
654\end{array}$ & $\begin{array}{c}2.077 . \\
950\end{array}$ & $\begin{array}{c}2.462 \\
604\end{array}$ & $\begin{array}{c}29.377 . \\
115\end{array}$ & $\begin{array}{c}27.869 \\
801\end{array}$ & $\begin{array}{c}57.246 . \\
916\end{array}$ \\
\hline 2017 & $\begin{array}{c}30.398 \\
505\end{array}$ & $\begin{array}{c}30.618 \\
652\end{array}$ & $\begin{array}{c}61.01 \\
157\end{array}$ & $\begin{array}{l}356 . \\
073\end{array}$ & $\begin{array}{c}1.974 . \\
567\end{array}$ & $\begin{array}{c}2.330 \\
640\end{array}$ & $\begin{array}{c}29.818 \\
483\end{array}$ & $\begin{array}{c}28.395 \\
309\end{array}$ & $\begin{array}{c}58.213 \\
792\end{array}$ \\
\hline 2018 & $\begin{array}{c}30.814 . \\
302\end{array}$ & $\begin{array}{c}31.029 . \\
794\end{array}$ & $\begin{array}{c}61.84 . \\
096\end{array}$ & $\begin{array}{c}325 . \\
116\end{array}$ & $\begin{array}{c}1.872 \\
141\end{array}$ & $\begin{array}{c}2.197 \\
257\end{array}$ & $\begin{array}{c}30.25 \\
344\end{array}$ & $\begin{array}{c}28.898 \\
663\end{array}$ & $\begin{array}{c}59.156 . \\
007\end{array}$ \\
\hline
\end{tabular}

Kaynak: TÜİK, Ulusal Eğitim İstatistikleri Veri Tabanından oluşturulmuştur, 2019.

Temel insan hakları arasında yer alan "eğitim hakkı" ve eğitimde firsat eşitliği İnsan Hakları Evrensel Bildirgesinde "Her bireyin eğitim görme hakk1 vardır" şeklinde belirtilmiştir. Bu bağlamda eğitime erişim hakkı her birey için maddi, bölgesel, biyolojik fark aranmaksızın eşit olmalıdır. Ancak Tablo 8 incelendiğinde tüm yıllar itibariyle okuryazar olmayan kadın nüfusun erkek okuryazar olmayan nüfusun ortalama 5 katı olduğu görülmektedir. Yetişkin kadın nüfus içinde 15 yaş nüfus üzeri kadın okumaz- yazmazlık oranı ise $\% 6,5$ civarındadır. Eğitim hakkı kapsamında bir eşit erişim hakkı veya erişim 
"haksızlığı" olduğu ifade edilebilir. Ayrıca eğitim alanında yapılan düzenlemelerle birlikte tablodan da görüleceği üzere her geçen yıl bir iyileşme kendini göstermektedir. Her ne kadar erkeklerde bu iyileşme kadınlara nazaran oransal ve sayısal anlamda daha hızlı olsa da doğru adımlar atıldığında eğitim anlamındaki eşitsizlik sonlandırılabilir.

\section{SONUÇ}

Feminizm, toplumsal cinsiyet ayrımcılığına, toplumsal yaşamın tüm yönlerinde kadınların yaşadıkları sorunlara ve ikincil konumda görülmelerine çözüm yolları bulmayı amaçlamaktadır. Çalışmada feminist teori temelinde sosyal, siyasal ve ekonomik alanlarda kadınların erkeklerle eşit koşullara ve eşit haklara sahip olması üzerinde durulmuş olup, toplumsal cinsiyet eşitliği Türkiye özelinde istatistiki verilerden yararlanılarak genel bir çerçevede sunulmaya çalışılmıştır. Türkiye'de de başta anayasa olmak üzere kanun ve kalkınma planlarında kadın erkek firsat eşitliğinin sağlanmasına yönelik düzenlemeler yapılmıştır.

Çalışma kapsamında ele alınan yasal düzenlemeler ile en azından mevzuat anlamında ve hukuk nezdinde kadın-erkek eşitliğinin sağlandığı görülmektedir. Ancak çalışmada genel ve yerel siyasette kadın temsiline ilişkin ortaya konan veriler neticesinde uygulamada bu düzenlemelerin yeterli düzeyde etkili olmadığı, kadınların siyasal hayata katılımının erkeklere oranla düşük olduğu görülmektedir. Genel görünümde ortaya çıkan bu sonuçta toplumsal cinsiyetin bir parçası olan geleneksel değer yargıların etkisinin varlığı vurgulanabilir. Ayrıca kadınların ve erkeklerin çalışacakları işlerin sınıflandırılmış olması ve "siyasetin erkek işi”" olarak algılanması kadınların siyasal hayata katılmalarında engel olmakta ve kadınların kamuya girmelerinin ancak erkek kimliğine bürünmeleri ile gerçekleştiği görülmektedir. Bu durumda kadın-erkek eşitliği bağlamında siyasal ve sosyal alan açısından katılım sorunsalı önemli bir göstergedir. Türkiye ölçeğindeki temel göstergeler dikkate alındığında kadınların siyasal hayata katılması konusunda temel sorunun sadece toplumsal cinsiyet rollerine ilişkin kabullerin olmadığ 
ifade edilebilir. Bu bağlamda kadınların sorunlarına çözüm bulabilmeleri için siyasete daha çok katılımları önem taşımaktadır.

Çalışmada ele alınan diğer bir konu ise toplumsal cinsiyet olgusunun eğitime yansımalarının TÜİK verileri ile gösterilmesidir. Erkek ve kadınların okuryazarlık oranlarının eşit olmasına rağmen okuryazar olmayan kadın sayısının erkek sayısı ile kıyaslandığında çok yüksek olduğu görülmüştür. Eğitim hakkından mahrum kalma ya da eğitim hakkına toplumsal cinsiyet rollerinden dolayı erişememek, kadını ev dışı toplumsal hayatın tümünden soyutlamak ile eş değer oldu ifade edilebilir. Okuma- yazma bilmeyen eğitimsiz birey gerek toplumsal ilişkiler gerek siyasal yaşam gerekse istihdama yönelik tüm haklarından mahrum kalmakta ya da mahrum edilmektedir. Bu bağlamda kadın bireylerin eğitim düzeyinin yükselmesi salt "eğitimli kadın" değil aynı zamanda toplumsal yaşama "adapte kadın”, siyasal katılımı yüksek kadın ve çalışma hayatında ve sosyal yaşamda "var olan" kadın anlamına geldiğinden, kadının eğitim düzeyinin yükseltilmesi toplumsal cinsiyet eşitliği noktasında önemli adımlar atılması anlamına gelmektedir.

Kadınların çalışma yaşamına girmesi konusunda yasalarda cinsiyete dayalı ayrımcılık bulunmamaktadır. 4857 sayılı İş Kanunu'nda kadın-erkek işçi ücretleri eşitliği ayrıca düzenlenmiştir. İş Kanunu'nun 5.maddesinde işçinin cinsiyeti nedeniyle özel koruyucu hükümlerin uygulanmasının, daha düşük bir ücretin uygulanamayacağı ifade edilmiştir. Ayrıca İş Kanunu'nda kadın işçiye özel olarak korunması gereken alanlarda da (hamilelik, analık vb.) bazı haklar tanınmaktadır. Kadınların işgücüne dâhil olmama nedenleri arasında ise sebep olarak en çok gösterilen neden ev işleri ile meşgul olmadır. Çalışma isteği ve gücü olan kadını toplumsal cinsiyet rollerinden ötürü ev hayatına mahkûm etme, emeğinin karşıllı̆ını alamadığı ve minimal düzeyde ücretlerde çalışmaya mecbur kaldığı "atipik "işlerde çalışma hayatını sunmaktadır. Kadınlar kendi evlerinde maddi değer atfedilmeyen ev işlerini bir başka kadının evinde yaparak, çalışma güvencesi ve sosyal güvenliği olmayan "maddi" ve "gündelik" işlerle aile bütçesine katk1 sağlamaktadır. Bunun dişında "ev içi “işlerini aksatmadan özel alanlarında parça başı işler yaparak ev ekonomisine katkı yapmalarına rağmen bu emekleri uzun vadede 
iş güvencesi ve sosyal güvenlik sağlamadığından, dahası minimal ücret olanağı sunduğundan durumu daha da vahim hale getirmektedir.

Toplumsal yapı ve ilişkiler gözlemlendiğinde ifade edilebilir ki toplumsal cinsiyet rolleri sadece erkekler tarafından değil kadınlar tarafından benimsenmiştir. $\mathrm{Bu}$ anlamda yürütülecek bilinçlendirme çalışmalarının, toplumun bütün kesimlerini kapsayacak şekilde yapılması gerektiği önem arzetmektedir.

\section{KAYNAKLAR}

Aktaş, G. (2013). Feminist Söylemler Bağlamında Kadın Kimliği: Erkek Egemen Bir Toplumda Kadın Olmak. Edebiyat Fakültesi Dergisi, 30/1, 53-70.

Arıkboğa, E. (2009). Yerel Yönetimlerde Kadın Temsil ve Kadın Üyeler: Kadın Adayların Önündeki Görünmez Engeller. Türk İdare Dergisi, 15-43.

Çakır, S. (2018). Feminizm, Birsen Örs (Der), 19. Yüzylldan 20. Yüzyıla Modern Siyasal İdeolojiler içinde, (s. 413-476), (9. Bask1). İstanbul: İstanbul Bilgi Üniversitesi Yayınları.

Dikici, E. (2016). Feminizmin Üç Ana Akımı: Liberal, Marxist ve Radikal Feminizm Teorileri. International Journal of Social Science, 43/1, 523-532.

Dökmen, Z. (2004). Toplumsal Cinsiyet. İstanbul: Sistem Yayınc1lık.

Eroğlu, F. (2011). Avrupa Ülkeleri Anayasalarında Toplumsal Cinsiyet ve Kadın-

Erkek Eşitliği ile İlgili Düzenlemeler. Ankara: Türkiye Büyük Millet Meclisi Kadın Araştırma Merkezi.

Ersoy, E. (2009). Cinsiyet Kültürü İçerisinde Kadın ve Erkek Kimliği (Malatya Örneği). Furat Üniversitesi Sosyal Bilimler Dergisi, 19/2, 209-230.

Giddens, A. (2008). Sosyoloji. İstanbul: Kırmızı Yayınları.

Heywood, A. (2010). Siyasi İdeolojiler. (2.Baskı). İstanbul: Adres Yayınları.

Kapucu, Ş. N. (2008). Kadınların İstihdama Katılımını Etkileyen Faktörler, (Yayınlanmamış Yüksek Lisans Tezi), Gazi Üniversitesi.

Kavas, A. (2018). Karşılaştırmalarla 81 İl İçin Toplumsal Cinsiyet Eşitliği Karnesi. TEPAV.

Koray, M. (2011). Avrupa Birliği ve Türkiye'de "Cinsiyet” Eşitliği Politikaları: SolFeminist Bir Eleştiri. Çalışma ve Toplum Dergisi, Sayı 2.

Notz, G. (2018). Feminizm. S. D. Çetinkaya (Çev.). Ankara: Phoenix Yayınevi.

Özçatal, E. Ö. (2011). Ataerkillik, Toplumsal Cinsiyet ve Kadınının Çalışması. Çankırı Karatekin Üniversitesi İktisadi ve İdari Bilimler Fakültesi Dergisi, 2129. 
Saraç, S. (2013). Toplumsal Cinsiyet ve Yansımaları, Ankara: Atılım Üniversitesi Yayınları.

Şahin, F. (2011). Kadınların Siyasal Katılımları Çerçevesinde Kadın Meclislerinin Yerel Siyasetteki Etkinlikleri ve Üye Profilleri. Ankara: T.C Başbakanlık Kadının Statüsü Genel Müdürlüğü.

Turan, H. (2013). Belediyelerde Toplumsal Cinsiyet Eşitliği Uygulamaları: Büyükşehir Belediyelerinin Stratejik Planları Üzerine Bir Araştırma, (Yayınlanmamış Yüksek Lisans Tezi). Sakarya Üniversitesi/Sosyal Bilimler Enstitüsü.

Türeli N., ve Çağlar N. (2010). Yerel Yönetimde Kadın Temsili- Isparta İli Örneği. Süleyman Demirel Üniversitesi Vizyoner Dergisi, 2, 1.

Türkoğlu, E. (2015). Uluslararası İlişkiler Kuramında Feminizm, (Yayınlanmamış Yüksek Lisan Tezi). Selçuk Üniversitesi /Sosyal Bilimler Enstitüsü

Yıldız, E. (2003). Toplumsal Cinsiyetle Yoksulluk İlişkisi Nasıl Kurulabilir? Bu İlişki Nasıl Çalışabilir. Cumhuriyet Üniversitesi Tıp Fakültesi Dergisi, Özel Eki.

Yumuş, A. (2011). Kalkınma Planları Çerçevesinde Toplumsal Cinsiyet Eşitliği Anlayışının Ekonomik Toplumsal ve Siyasal Boyutları. Ankara: T.C. Başbakanlık Kadının Statüsü Genel Müdürlüğü.

4857 Sayılı İş Kanunu. (2003). Sayı: 25134 Resmî Gazete: 10.6.2003.

5216 Sayılı Büyükşehir Belediyesi Kanunu. (2004). Sayı: 25531, Resmî Gazete 10.7.2004.

5393 Say11 Belediye Kanunu. (2005). Say1: 25874, Resmî Gazete: 13.07.2005.

Beş Yıllık Kalkınma Planları, T.C. Başkanlığı Strateji ve Bütçe Başkanlığı www.sbb.gov.tr/kalkinma-planlari adresinden alındı.

Global Gender Gap Report 2020,

http://www3.weforum.org/docs/WEF_GGGR_2020.pdf adresinden alınd1.

KADEM, http://kadem.org.tr/kadin-siyaset-ve-demokrasi/adresinden alındı.

Küresel Cinsiyet Eşitsizliği, https://insanhaklarimerkezi.bilgi.edu.tr/tr/news/nonedunya-ekonomiforumu-2017-kuresel-cinsiyet-es/ adresinden alındı.

TÜIKK Merkezi Dağıtım Sistemi, https://biruni.tuik.gov.tr/medas/?locale=tr adresinden alındı.

Türkiye Cumhuriyeti Anayasas1. (1982). Kabul Tarihi: 7.11.1982.

YSK, 27. Dönem Milletvekili Seçimi, www.ysk.gov.tr adresinden alındı. 